\title{
Kinetic Characterization and Effect of Immobilized Thermostable $\beta$-Glucosidase in Alginate Gel Beads on Sugarcane Juice
}

\author{
Keerti, ${ }^{1}$ Anuradha Gupta, ${ }^{1}$ Vinod Kumar, ${ }^{1,2}$ Ashutosh Dubey, ${ }^{1}$ and A. K. Verma ${ }^{1}$ \\ ${ }^{1}$ Department of Biochemistry, College of Basic Sciences and Humanities, G. B. Pant University of Agriculture and Technology, \\ Pantnagar 263145, India \\ ${ }^{2}$ Akal School of Biotechnology, Eternal University, Baru Sahib, Sirmour 173101, India
}

Correspondence should be addressed to A. K. Verma; akv72@rediffmail.com

Received 17 November 2013; Accepted 16 December 2013; Published 20 February 2014

Academic Editors: P. Maher and D. Stapleton

Copyright (C) 2014 Keerti et al. This is an open access article distributed under the Creative Commons Attribution License, which permits unrestricted use, distribution, and reproduction in any medium, provided the original work is properly cited.

\begin{abstract}
A thermostable $\beta$-glucosidase was effectively immobilized on alginate by the method of gel entrapment. After optimization of immobilized conditions, recovered enzyme activity was $60 \%$. Optimum $\mathrm{pH}$, temperature, kinetic parameters, thermal and $\mathrm{pH}$ stability, reusability, and storage stability were investigated. The $K_{m}$ and $V_{\max }$ for immobilized $\beta$-glucosidase were estimated to be $5.0 \mathrm{mM}$ and $0.64 \mathrm{U} / \mathrm{ml}$, respectively. When comparing, free and immobilized enzyme, change was observed in optimum $\mathrm{pH}$ and temperature from 5.0 to 6.0 and $60^{\circ} \mathrm{C}$ to $80^{\circ} \mathrm{C}$, respectively. Immobilized enzyme showed an increase in pH stability over the studied $\mathrm{pH}$ range (3.0-10.0) and stability at temperature up to $80^{\circ} \mathrm{C}$. The storage stability and reusability of the immobilized $\beta$-glucosidase were improved significantly, with $12.09 \%$ activity retention at $30^{\circ} \mathrm{C}$ after being stored for $25 \mathrm{~d}$ and $17.85 \%$ residual activity after being repeatedly used for 4 times. The effect of both free and immobilized $\beta$-glucosidase enzyme on physicochemical properties of sugarcane juice was also analyzed.
\end{abstract}

\section{Introduction}

$\beta$-Glucosidase ( $\beta$-D-glucoside glucohydrolase; EC 3.2.1.21) is a part of multienzyme cellulase complex, whose synthesis and action are intricately controlled by regulatory mechanisms in the organisms that produce these enzymes. The enzymatic hydrolysis of cellulose involves three types of cellulase activities (cellobiohydrolases, endoglucanases, and $\beta$-glucosidases) working in synergy $[1,2]$.

$\beta$-Glucosidases hydrolyze $\beta$-D-glycosidic bond to release nonreducing $\beta$-D-glucose residue and terminal aglycone. These are widely used in the various biotechnological processes including aroma and flavour enrichment [3], discoloration of fruit juices prevention [4], and organoleptic properties of citrus fruit juices improvement, in which the bitterness is in part due to a glucosidic compound, naringin (4,5,7-trihydroxyflavanone-7-rhamnoglucoside) [5]. $\beta$-Glucosidase also acts as a key enzyme in the enzymatic release of aro-matic compounds from glucosidic precursors present in fruits and fermentation products [6]. Transglycosylation reactions by $\beta$-glucosidase have great importance in wine or beverage industry because of their abilities to improve the aroma [7]. The synthetic activity of $\beta$-glucosidase can be used in the preparation of a variety of compounds such as oligosaccharides and glycoconjugates that have potential for use as agrochemicals and drugs. $\beta$-Glucosidase, produced intracellularly by many microorganisms, usually shows a broad specificity and also transferase activity [8].

Nevertheless, the applications of enzyme in industry remain limited due to the high production cost, stability, and need for repeated enzyme purification. The main strategy to increase the enzyme stability and reusability is the immobilization of enzyme. Some of the more significant advantages of immobilized enzymes over their soluble counterparts include the enhanced stability under extreme conditions of temperature, $\mathrm{pH}$, and organic solvents; recovery; and subsequent applicability to continuous processes [9]. 
Alginate, a polysaccharide consisting of glucuronic acid and mannuronic acid moieties, has been found to be a matrix of priority due to its biocompatibility and processivity [10]. It is a reversibly soluble insoluble polymer which changes solubility in the presence of calcium [11]. To date, cross-linked alginate has been successfully used for encapsulation of many biological molecules $[12,13]$.

The present study describes the immobilization of $\beta$-glucosidase in alginate gel beads and the effect of this immobilization on kinetic characteristics of immobilized $\beta$-glucosidase in comparison with free enzyme. For application purposes, the effect of both free and immobilized $\beta$-glucosidase enzymes on physicochemical properties of sugarcane juice was also analyzed.

\section{Material and Methods}

2.1. Chemicals and Bacterial Culture. All chemicals, media, and components used were of analytical grade and obtained from Sigma Chemicals Ltd., Himedia Laboratories Ltd., GeNei, SRL, and Merck Pvt. Ltd. Recombinant $\beta$-glucosidase from Bacillus subtilis strain PS (identified using 16S rDNA sequencing; GenBank Accession number JQ066263) cloned in E. coli $\mathrm{DH} 5 \alpha$ in our laboratory was used in this study [14]. The cloned $\beta$-glucosidase produces extracellularly by the bacterial cell.

2.2. Production and Partial Purification of $\beta$-Glucosidase. E. coli $\mathrm{DH} 5 \alpha$ containing recombinant enzyme was cultured in Luria broth in $250 \mathrm{~mL}$ conical flasks using incubator shaker $(150 \mathrm{rpm})$ at $37^{\circ} \mathrm{C}$ for $12 \mathrm{~h}$. For extraction of extracellular $\beta$-glucosidase enzyme, cells were harvested at $10,000 \mathrm{rpm}$ for 30 minutes at $4^{\circ} \mathrm{C}$ and supernatant was collected and assayed for $\beta$-glucosidase activity. $\beta$-Glucosidase enzyme was purified partially using ammonium sulfate fractionation followed by dialysis. All the purification steps were performed at $4^{\circ} \mathrm{C}$. Crude enzyme in the cell free supernatant was precipitated by adding ammonium sulfate up to $70 \%$. The precipitates were separated by centrifugation and resuspended in acetate buffer (100 mM, pH 5.0) and dialyzed against the same buffer overnight with two buffer changes. The $\beta$-glucosidase activity after dialysis was measured and it was used for further studies.

\subsection{Immobilization of $\beta$-Glucosidase in Ca-Alginate Gel Beads.} Calcium alginate gel beads were prepared as described by Busto et al. [15]. Briefly, sodium alginate solution, $1 \%, 2 \%$, $3 \%, 4 \%$, and $5 \%$, was prepared in a suitable amount of enzyme. This solution was dropped in $0.05 \mathrm{M}, 0.1 \mathrm{M}$, and $0.2 \mathrm{M}$ calcium chloride solution under continuous stirring. The beads were cured for $1-5 \mathrm{hrs}$ in the calcium chloride solution, washed several times with a $0.03 \mathrm{M} \mathrm{CaCl}_{2}$ solution until no enzyme activity was observed in the final washing, and stored at $4^{\circ} \mathrm{C}$ in this solution.

2.4. Determination of $\beta$-Glucosidase Enzyme Activity. $\beta$-Glucosidase activity was evaluated spectrophotometrically using pNPG as an artificial substrate. The reaction mixture, containing $100 \mu \mathrm{L} \beta$-glucosidase enzyme extract in acetate buffer ( $\mathrm{pH} 5.0,100 \mathrm{mM}$ ) and $100 \mu \mathrm{L}$ of $\mathrm{pNPG}$ in similar buffer, was incubated for $30 \mathrm{~min}$ at $60^{\circ} \mathrm{C}$. The reaction was stopped by adding $2 \mathrm{~mL}$ of $1 \mathrm{MNa}_{2} \mathrm{CO}_{3}$ solution and the absorbance was measured at $\lambda_{405} \mathrm{~nm}$ [16]. The activity of immobilized $\beta$-glucosidase was determined using the procedure given above except $0.2 \mathrm{~g}$ immobilized enzyme was used in place of $100 \mu \mathrm{L}$ enzyme extract.

2.5. Kinetic Characterization of Immobilized and Free Enzyme. The kinetic constants of Michaelis values $\left(K_{m}\right.$ and $\left.V_{\max }\right)$ for the free and immobilized enzyme preparations were determined using Lineweaver-Burk plot by measuring the enzymatic activity at different substrate concentrations (1$15 \mathrm{mM}$ ). The turnover number and catalytic efficiency were also determined.

2.6. Effect of $p H$ and Temperature on Free and Immobilized $\beta$-Glucosidase Activity. The optimum $\mathrm{pH}$ for $\beta$-glucosidase activity was studied over a $\mathrm{pH}$ range of 3 to 10 to determine the activity of free as well as immobilized enzyme. Citrate buffer ( $\mathrm{pH}$ 3-6), phosphate buffer ( $\mathrm{pH} 7-8$ ), and glycine$\mathrm{NaOH}$ buffer ( $\mathrm{pH}$ 9-10) were used to determine enzyme activity. The optimum temperature for $\beta$-glucosidase activity was determined by incubating the reaction mixture over the temperature range of $40-80^{\circ} \mathrm{C}$ at the optimum $\mathrm{pH}$.

\subsection{Effect of $p H$ and Temperature on Stability of Extracellular} Free $\beta$-Glucosidase. The stability of the enzyme was determined by preincubating the enzyme for $30 \mathrm{~min}$ at $37^{\circ} \mathrm{C}$ with various buffers having a $\mathrm{pH}$ range of 3 to 10 as mentioned earlier. After incubation, the residual enzyme activity (\%) was measured using acetate buffer $(\mathrm{pH}$ 5.0) as explained earlier. The thermal stability of the enzyme was studied by preincubating the enzyme at different temperatures ranging from 40 to $80^{\circ} \mathrm{C}$ for $0-120 \mathrm{~min}$ at optimum $\mathrm{pH}$.

2.8. Storage Stability and Reusability of Immobilized $\beta$-Glucosidase. The storage stability of immobilized $\beta$-glucosidase at $4^{\circ} \mathrm{C}$ and $30^{\circ} \mathrm{C}$ was measured by calculating the residual activity at the interval of $5 \mathrm{~d}$ up to $30 \mathrm{~d}$. Reusability of immobilized enzyme was also investigated by measuring its activity after repeated cycles of use.

2.9. Estimation of Reducing Sugar in Sugarcane Juice. Sugarcane juice was incubated at $60^{\circ} \mathrm{C}$ for $30 \mathrm{~min}$ in the presence of free and immobilized $\beta$-glucosidase in alginate gel and the reducing sugar was estimated by Somogyi's method [17]. Determination of relative density and viscosity coefficient of treated sugarcane juice with free and immobilized enzyme was done by density bottle method and Ostwald's viscometer.

2.10. Absorption Spectra of Sugarcane Juice. Sugarcane juice was incubated for $30 \mathrm{~min}$ at $60^{\circ} \mathrm{C}$ in the presence of free and immobilized $\beta$-glucosidase and then the samples were diluted to five times with distilled water. The absorption spectra of untreated and treated juice were analyzed in visible range $(400-700 \mathrm{~nm})$. 


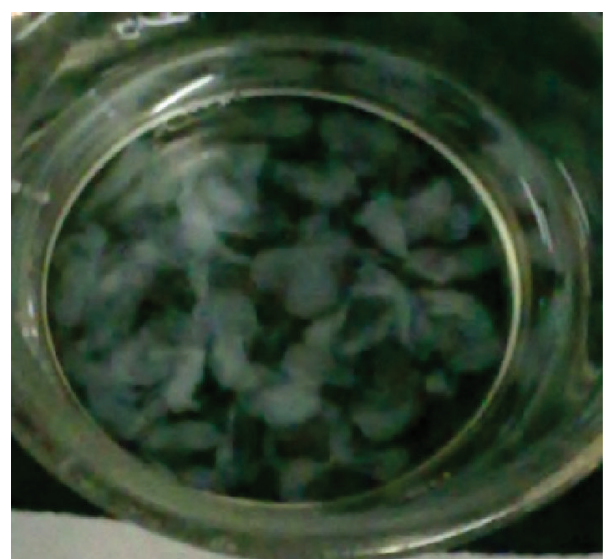

(a)

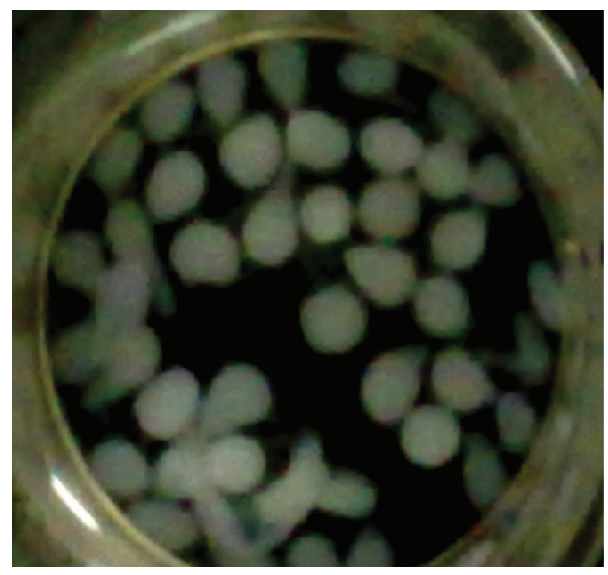

(c)

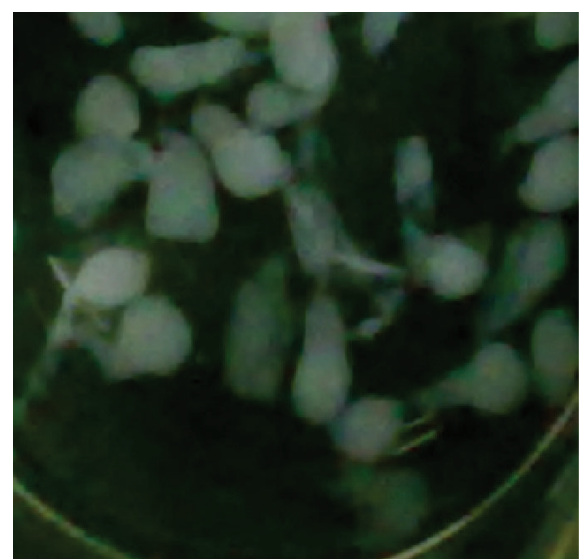

(b)

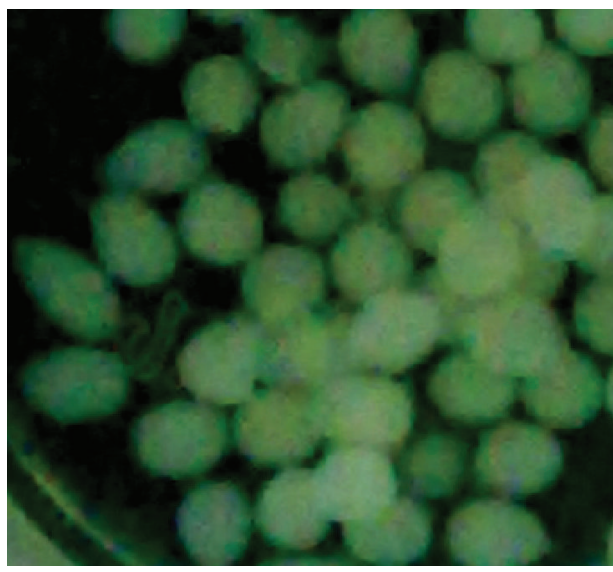

(d)

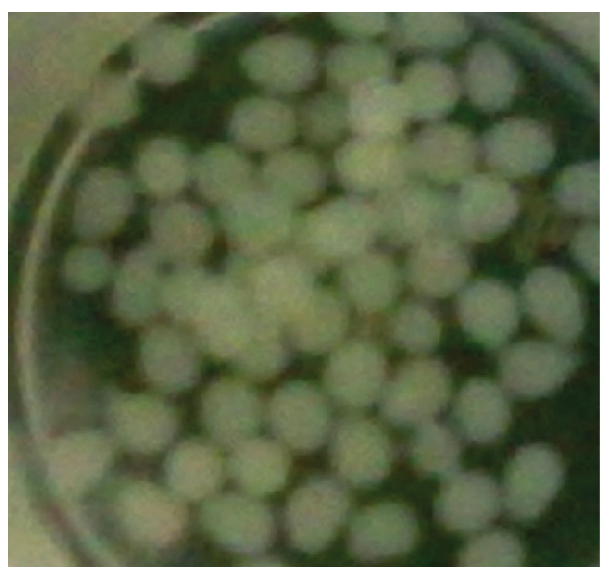

(e)

FIGURE 1: Immobilization of $\beta$-glucosidase in different concentrations of sodium alginate ((a) $1 \%$ sodium alginate; (b) $2 \%$ sodium alginate; (c) $3 \%$ sodium alginate; (d) $4 \%$ sodium alginate; (e) $5 \%$ sodium alginate).

2.11. Statistical Analysis. The mean values and standard deviation of three experiments were calculated and presented on the figures as error bars. One-way ANOVA at the significance levels of 0.005 and 0.001 was performed using Microsoft excel 2007 statistical tools.

\section{Results and Discussion}

3.1. Immobilization of $\beta$-Glucosidase in Gel. The effects of $\mathrm{Na}$-alginate and $\mathrm{CaCl}_{2}$ concentrations on the bead formation and immobilization of enzyme revealed that maximum 
immobilization efficiency (60\% $\beta$-glucosidase activity) was obtained with $3 \%$ sodium alginate and $0.2 \mathrm{M} \mathrm{CaCl}_{2}$ for $1 \mathrm{~h}$ (Figure 1). A similar high level of activity was obtained by Ortega et al. [18], where $\beta$-glucosidase from Aspergillus niger was immobilized in calcium alginate, using an alginate concentration of $3 \%$. No significant effect was observed on the $\beta$-glucosidase immobilization with various concentrations of the immobilization time. On increasing $\mathrm{CaCl}_{2}$ concentration from 0.05 to $0.2 \mathrm{M}$, the stability of the gel increased without loss of enzyme activity, which was in agreement with the results obtained by Jain and Ghose [19]. Lower immobilization efficiency of $\beta$-glucosidase at sodium alginate concentrations below 3\% was suggested to be due to larger pore sizes of the less tightly cross-linked gels [20], and at sodium alginate concentrations above $3 \%$ might be due to lack of uniform pore size because of high viscosity of the enzyme alginate mixture.

3.2. Kinetic Characteristics of Free and Immobilized $\beta$ Glucosidase. The effect of the substrate concentration on the rate catalyzed by free and immobilized enzyme was studied using varying concentrations $(1-15 \mathrm{mM})$ of $\mathrm{pNPG}$ as the substrate. Michaelis constant $\left(K_{m}\right)$ and the maximum reaction velocity $\left(V_{\max }\right)$ of free and immobilized enzyme were calculated from the Lineweaver-Burk plot. The immobilized enzyme in alginate showed an apparent $K_{m}$ value $\left(K_{m}=\right.$ $5.0 \mathrm{mM})$ higher than the free enzyme $\left(K_{m}=3.6 \mathrm{mM}\right)$. Similar results were reported by Quiroga et al. [21] for immobilized araujiain, a cysteine phytoprotease in calcium alginate gel beads. An increase in $K_{m}$ after immobilization indicates that the immobilized enzymes have an apparent lower affinity for their substrate than the free enzyme. This may be caused by the support steric hindrance of the active site, by the loss of enzyme flexibility necessary for substrate binding, or by diffusional resistance to substrate transport [22]. In addition, a decrease in $V_{\max }$ was observed for immobilized enzyme $\left(0.745 \mu \mathrm{mol} \mathrm{min}-1 \mathrm{~mL}^{-1}\right)$ as compared to free enzyme $\left(0.94 \mu \mathrm{mol} \mathrm{min}{ }^{-1} \mathrm{~mL}^{-1}\right)$. This decrease might be attributed to limited accessibility of substrate molecules to the active sites of the enzyme and the interaction of the enzymes with the functional groups on the surface of beads or large areas of contact between enzyme and support. The apparent $K_{\text {cat }}$ values of free and immobilized $\beta$-glucosidase under standard assay conditions were $3.13 \times 10^{-4} \mathrm{~s}^{-1}$ and $4.15 \times 10^{-4} \mathrm{~s}^{-1}$, respectively. The catalytic efficiency of free and immobilized $\beta$-glucosidase was $0.87 \times 10^{-4}$ and $0.83 \times 10^{-4}$, respectively.

3.3. Effect of Temperature on Free and Immobilized $\beta$ Glucosidase. Effect of temperature variations on free and immobilized enzyme activity was investigated. Reactions were carried out at $\mathrm{pH} 6.0$ and temperature influence was studied within the $40-90^{\circ} \mathrm{C}$ range (Figure 2 ). The optimum temperature of the free enzyme was $60^{\circ} \mathrm{C}$ but after the entrapment process a shift in such temperature was observed and the immobilized enzyme exhibited the highest activity

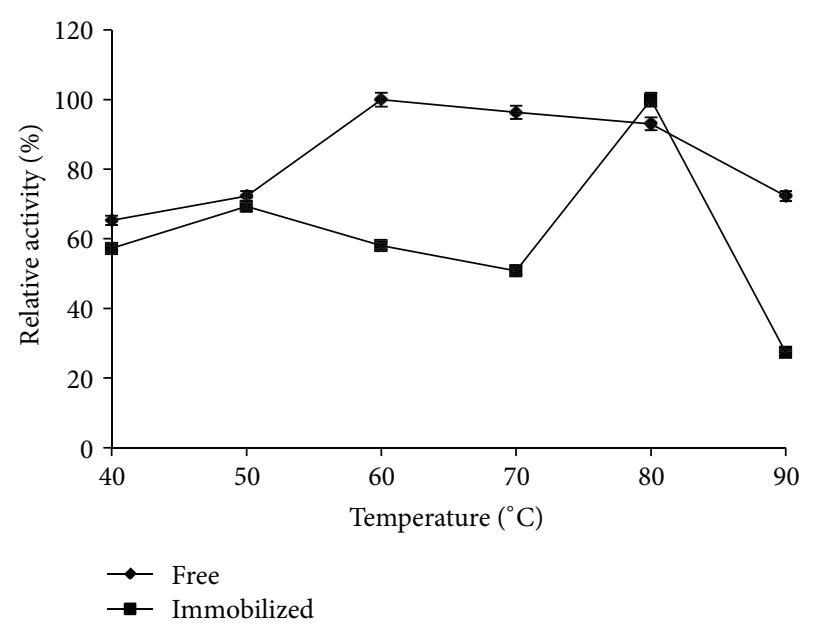

Figure 2: Relative activity (\%) of free and immobilized $\beta$ glucosidase at different temperatures.

at $80^{\circ} \mathrm{C}$ in gel, since hydrophobic and other secondary interactions of the immobilized enzyme might impair conformational flexibility needing higher temperatures for the enzyme molecule to recognize and attain a proper conformation in order to keep its reactivity [23]. Thereafter, a loss in activity above $80^{\circ} \mathrm{C}$ might be due to the denaturation of some enzyme molecules, leaching of enzyme from the swollen polymer matrix, and degradation of polymer matrix [24]. Further, the high activity of immobilized enzyme at $50^{\circ} \mathrm{C}$ probably is a result of favoured adsorption of enzymes [25]. Lower activity of the immobilized enzyme has been observed during these assays as compared to the free enzyme. It might be due to decreased affinity of the enzyme for the substrate caused by internal diffusion of the immobilized enzyme [26].

The dependence of the rate constant on temperature of an enzyme catalyzed reaction can be represented by the Arrhenius equation [27]. For many reactions, the $E_{a}$ values are in the range of $50-100 \mathrm{KJ} \mathrm{mol}^{-1}$. But in the case of enzyme catalyzed reactions, the $E_{a}$ values are generally lower than those of non-enzyme-catalyzed reactions. The observed activation energies for free and immobilized enzyme were 54 and $14.44 \mathrm{KJ} \mathrm{mol}^{-1}$, respectively. Similar results were obtained in case of aminoacylases immobilized by alkylation with iodoacetyl cellulose [28]. The values of $E_{a}$ for the immobilized enzyme are smaller than that for the free enzyme, implying that the immobilized enzymes are less sensitive [29].

The rates of thermal inactivation of the free and immobilized $\beta$-glucosidase were studied in the temperature range of $30-60^{\circ} \mathrm{C}$ and $50-80^{\circ} \mathrm{C}$ for $0-120 \mathrm{~min}$ (Figures 3(a) and $3(\mathrm{~b}))$. The results indicated that the free $\beta$-glucosidase was fairly stable at the temperature range from 50 to $60^{\circ} \mathrm{C}$ while the immobilized $\beta$-glucosidase was fairly stable at $60-80^{\circ} \mathrm{C}$. The above results suggest that the alginate matrix preserved the structure of the enzyme after immobilization process and it protected the enzyme from conformational changes caused by effects of temperature. The activity of immobilized enzyme decreased slowly and still retained $58 \%$ of its residual activity at $80^{\circ} \mathrm{C}$. Similar results were obtained in immobilized 


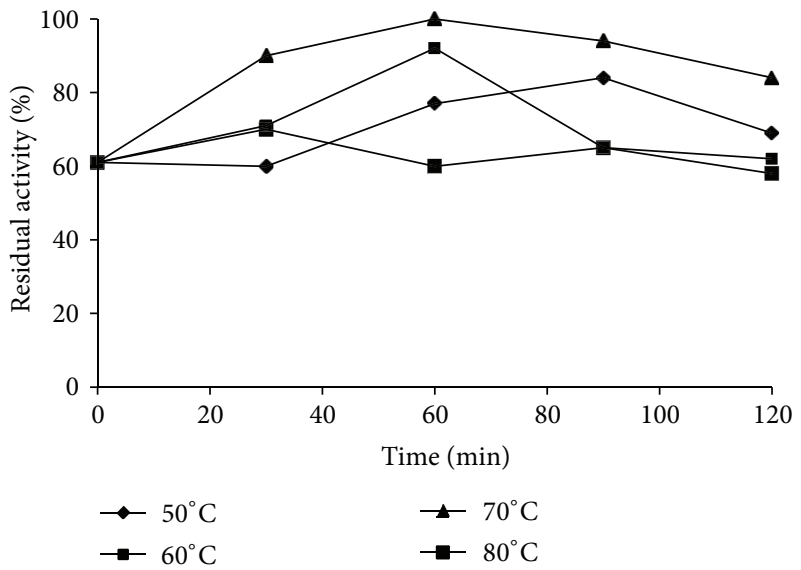

(a)

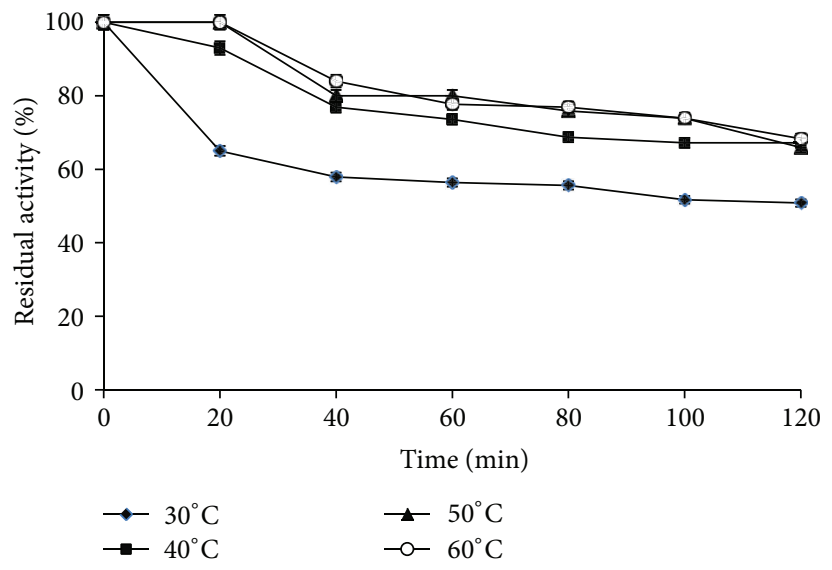

(b)

FIGURE 3: Residual relative activity (\%) of (a) immobilized and (b) free $\beta$-glucosidase to determine its stability at different temperatures.

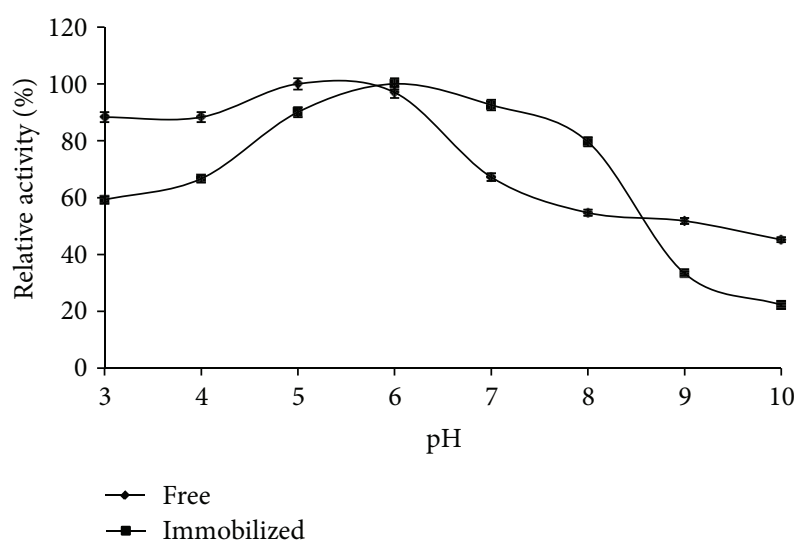

FIGURE 4: Effect of $\mathrm{pH}$ on the relative activity of free and immobilized $\beta$-glucosidase.

araujiain without any significant loss in its activity at the studied temperatures [21]. The thermal stability of immobilized $\beta$-glucosidase increased considerably as a result of immobilization in the sodium alginate beads. This is because of immobilization and cross-linking which provided a more rigid external backbone for enzyme molecules. As a result, the effect of higher temperature in breaking the interactions that were responsible for the proper globular, catalytic active structure became less prominent, thus increasing the thermal stability of the immobilized enzyme [30].

3.4. Effect of $p H$ on Free and Immobilized $\beta$-Glucosidase. The optimum $\mathrm{pH}$ of free and immobilized $\beta$-glucosidase was studied at various $\mathrm{pH}$ values (3.0-10.0) (Figure 4). The results indicated that the optimum $\mathrm{pH}$ values of free and immobilized $\beta$-glucosidase were 5.0 and 6.0, respectively. The $\mathrm{pH}$ shifts towards alkaline value upon immobilization are suggested to be because of secondary interactions between the enzyme and the polymeric matrix $[31,32]$. The maximum activity range of immobilized enzyme over the $\mathrm{pH}$ 6.0-8.0

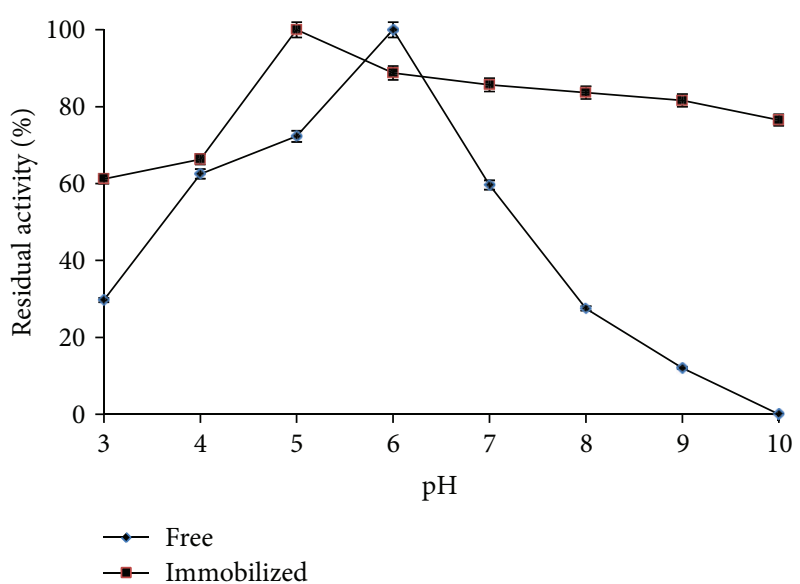

FIGURE 5: Residual relative activity (\%) of free and immobilized $\beta$ glucosidase to determine the stability at different $\mathrm{pH}$ values.

revealed its resistance to the alkaline changes in medium as compared to the free enzyme [21].

The $\mathrm{pH}$ stabilities of free and immobilized $\beta$-glucosidase are compared at different $\mathrm{pH}$ values (3.0-10.0) after incubation for $30 \mathrm{~min}$ at $37^{\circ} \mathrm{C}$ (Figure 5). The results showed that immobilized $\beta$-glucosidase in alginate gel had the highest stability around $\mathrm{pH}$ value of 5.0 , whereas the free $\beta$ glucosidase had the highest stability around $\mathrm{pH}$ 6.0. The activity of immobilized $\beta$-glucosidase was higher than that of free $\beta$-glucosidase at $\mathrm{pH}<4.0$ or $\mathrm{pH}>7.0$, suggesting that immobilization seems to confer some kind of protection to the enzyme when the reaction media presented a $\mathrm{pH}$ value at the scope of acidity or alkalescence [30]. Similar results were observed in case of immobilized laccase, where on magnetic chitosan microspheres it was stable in the $\mathrm{pH}$ range 5.0-6.0 while free laccase was stable in the $\mathrm{pH}$ range 7.0-9.0 [33]. This indicates that the immobilization appreciably improves the stability of laccase in the acidic region. Therefore, entrapped enzyme displays greater $\mathrm{pH}$ stability at optimum $\mathrm{pH}$ and 


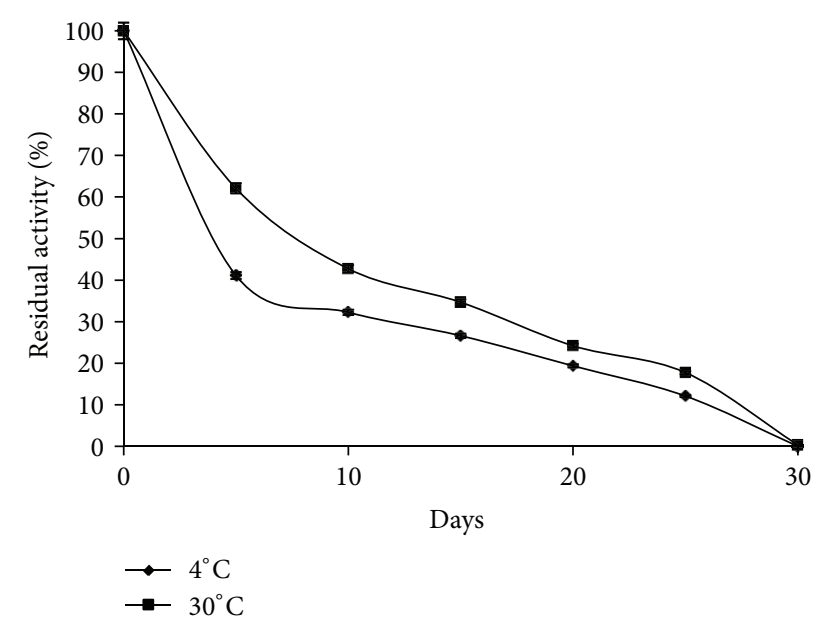

Figure 6: Activity retention (\%) of immobilized $\beta$-glucosidase at $4^{\circ} \mathrm{C}$ and $30^{\circ} \mathrm{C}$.

exhibits a better stability in neutral and basic medium than free enzyme.

3.5. Storage Stability and Reusability of Immobilized $\beta$ Glucosidase. Storage stability for the immobilized enzyme was one of the significant indexes to evaluate the properties of enzyme, which can make the immobilized enzyme more advantageous than that of the free one. In general, if an enzyme is in solution, it is not stable during storage, and the activity is gradually reduced [34]. The immobilized enzyme in alginate was stored for $30 \mathrm{~d}$ at $4^{\circ} \mathrm{C}$ and $30^{\circ} \mathrm{C}$. The residual activity was determined as a function of time (Figure 6). The residual activity of free $\beta$-glucosidase was found gradually decreasing to $3.05 \%$ from 0 to 4 th $\mathrm{d}$ at $4^{\circ} \mathrm{C}$ and no residual enzyme activity was observed after $1 \mathrm{~d}$ when the enzyme was stored at $30^{\circ} \mathrm{C}$. However, the immobilized $\beta$ glucosidase in alginate retained about $17.74 \%$ and $12.09 \%$ of its original activity at $4^{\circ} \mathrm{C}$ and $30^{\circ} \mathrm{C}$ after $25 \mathrm{~d}$, respectively. This extended stability could be attributed to the prevention of structural denaturation as a result of the immobilization of $\beta$-glucosidase. Yahşi et al. [35] reported that hydrogel carriers such as poly (acrylamide-co-acrylic acid) and Caalginate provide a protective microenvironment for enzymes and yield higher stabilities.

The reuse number of immobilized enzymes is one of the most important aspects for industrial application. An increased stability could make the immobilized enzyme more advantageous than the free form [30]. The immobilized $\beta$ glucosidase in alginate was reused for 4 times and the residual activity gradually decreased to $17.85 \%$. Thus the immobilized enzyme activities decreased while reused number increased. These results could be explained by the inactivation of enzyme caused by the denaturation and the leakage of enzyme from gels upon use and diffusional effects [36].

3.6. Treatment of Sugarcane Juice. The effect of both free and immobilized $\beta$-glucosidase enzyme on sugarcane juice was analyzed. It was observed that after sugarcane juice was

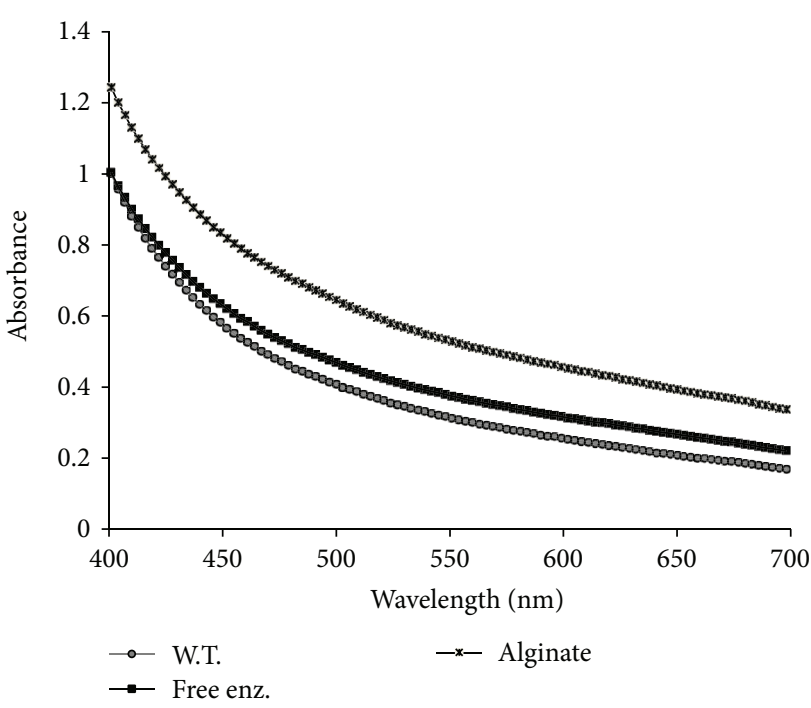

FIGURE 7: Absorption spectra of treated and untreated sugarcane juice by free and immobilized $\beta$-glucosidase (W.T.: juice without treatment, free enz.: juice treated with free $\beta$-glucosidase, and alginate: juice treated with immobilized $\beta$-glucosidase in alginate beads).

TABLE 1: Effect of free and immobilized enzyme on physicochemical properties of sugarcane juice.

\begin{tabular}{lccc}
\hline Type of juice & $\begin{array}{c}\text { Reducing } \\
\text { sugar }(\mathrm{g} / \mathrm{L})\end{array}$ & $\begin{array}{c}\text { Density } \\
(\mathrm{g} / \mathrm{mL})\end{array}$ & $\begin{array}{c}\text { Viscosity } \\
\text { (centipoise) }\end{array}$ \\
\hline $\begin{array}{l}\text { Untreated juice } \\
\begin{array}{l}\text { Treated with free } \\
\beta \text {-glucosidase }\end{array}\end{array}$ & 6.348 & 1.065 & 2.009 \\
$\begin{array}{l}\text { Treated with immobilized } \\
\beta \text {-glucosidase }\end{array}$ & 9.438 & 1.066 & 1.351 \\
\hline
\end{tabular}

treated with free and immobilized $\beta$-glucosidase for $30 \mathrm{~min}$ at $60^{\circ} \mathrm{C}$, the physicochemical properties of juice changed, such that viscosity of juice was decreased from 2.009 centipoise of untreated to 1.350 centipoise of treated with free $\beta$ glucosidase and 1.499 centipoise of treated with immobilized $\beta$-glucosidase. The reducing sugar was increased from $6.348 \mathrm{~g} / \mathrm{L}$ in untreated juice to $9.438 \mathrm{~g} / \mathrm{L}$ in free $\beta$-glucosidase and $8.134 \mathrm{~g} / \mathrm{L}$ in immobilized $\beta$-glucosidase (Table 1). While the absorption spectra of treated juice showed increased absorbance in the visible region (400-700 nm) (Figure 7), the increase of absorption spectra (hyperchromic shift) showed that the $\beta$-glucosidase hydrolyzed the glycosidic linkage between sugar and phenolic compounds present in the sugarcane juice. When these phenolic compounds are released, the sugarcane juice appears dark in colour. These glucosidic compounds play an important role in growth and reproduction, providing protection against pathogens and predators [37], besides contributing towards the colour and sensory characteristics of fruits and vegetables [38]. 


\section{Conclusion}

The $\beta$-glucosidase enzyme was successfully immobilized with the best immobilization efficiency obtained in 3\% sodium alginate in $0.2 \mathrm{M} \mathrm{CaCl}_{2}$ for $1 \mathrm{~h}$ of curing. The $K_{m}$ value of immobilized enzyme was higher than that of the free one which may be due to the decreased affinity of enzyme towards the substrate, whereas the $V_{\max }$ value of immobilized enzyme was lower than that of the free one which may be due to less accessibility of substrate to the enzyme. The immobilized enzyme exhibited a shift in optimum temperature from $60^{\circ} \mathrm{C}$ to $80^{\circ} \mathrm{C}$ which indicates that the immobilization process improves the activity and stability of $\beta$-glucosidase enzyme. The increased reusability, higher $\mathrm{pH}$ and storage stability of immobilized enzyme as compared to the free enzyme will be important for its sustained use and economic viability of biosynthetic processes.

\section{Conflict of Interests}

On behalf of all contributing authors, it is declared that there is no conflict of interests regarding this paper.

\section{References}

[1] L. R. Lynd, P. J. Weimer, W. H. van Zyl, and I. S. Pretorius, "Microbial cellulose utilization: fundamentals and biotechnology," Microbiology and Molecular Biology Reviews, vol. 66, no. 3, pp. 506-577, 2002.

[2] M. Dashtban and W. Qin, "Overexpression of an exotic thermotolerant $\beta$-lucosidase in trichoderma reese $i$ and its significant increase in cellulolytic activity and saccharification of barley straw," Microbial Cell Factories, vol. 11, article 63, 2012.

[3] Y. Gueguen, P. Chemardin, P. Labrot, A. Arnaud, and P. Galzy, "Purification and characterization of an intracellular $\beta$-glucosidase from a new strain of Leuconostoc mesenteroides isolated from cassava," Journal of Applied Microbiology, vol. 82, no. 4, pp. 469-476, 1997.

[4] V. A. Marinos, M. E. Tate, and P. J. Williams, "Protocol for FAB MS/MS characterization of terpene disaccharides of wine," Journal of Agricultural and Food Chemistry, vol. 42, no. 11, pp. 24862492, 1994.

[5] M. Roitner, T. Schalkhammer, and F. Pittner, "Characterisation of naringinase from Aspergillus niger," Monatshefte für Chemie, vol. 115, no. 10, pp. 1255-1267, 1984.

[6] O. Shoseyov, B. A. Bravdo, D. Siegel et al., "Immobilized endo$\beta$-glucosidase enriches flavor of wine and passion fruit juice," Journal of Agricultural and Food Chemistry, vol. 38, no. 6, pp. 1387-1390, 1990.

[7] J. Kaur, B. S. Chadha, B. A. Kumar, G. S. Kaur, and H. S. Saini, "Purification and characterization of $\beta$-glucosidase from $\mathrm{Mel}$ anocarpus sp. MTCC 3922," Electronic Journal of Biotechnology, vol. 10, no. 2, pp. 260-270, 2007.

[8] A. Sunna, M. Moracci, M. Rossi, and G. Antranikian, "Glycosyl hydrolases from hyperthermophiles," Extremophiles, vol. 1, no. 1, pp. 2-13, 1997.

[9] A. Illanes, Enzyme Biocatalysis: Principles and Applications, Springer Science, New York, NY, USA, 2008.

[10] L. W. Chan, H. Y. Lee, and P. W. S. Heng, "Production of alginate microspheres by internal gelation using an emulsification method," International Journal of Pharmaceutics, vol. 242, no. 1-2, pp. 259-262, 2002.

[11] O. Smidsrød and G. Skjåk-Braek, "Alginate as immobilization matrix for cells," Trends in Biotechnology, vol. 8, no. 3, pp. 71-78, 1990.

[12] M.-C. Chi, R.-C. Lyu, L.-L. Lin, and H.-B. Huang, "Characterization of Bacillus kaustophilus leucine aminopeptidase immobilized in Ca-alginate/k-carrageenan beads," Biochemical Engineering Journal, vol. 39, no. 2, pp. 376-382, 2008.

[13] A. Mittal, S. Khurana, H. Singh, and R. C. Kamboj, "Characterization of dipeptidylpeptidase IV (DPP IV) immobilized in Ca alginate beads," Enzyme and Microbial Technology, vol. 37, no. 3, pp. 318-323, 2005.

[14] S. Mondal, Cloning and expression of thermostable $\beta$-glucosidase gene in E. Coli for cellobiose degradation [M.S. thesis], Department of Biochemistry, G. B. Pant University of Agriculture and Technology, Pantnagar, India, 2010.

[15] M. D. Busto, N. Ortega, and M. Perez-Mateos, "Studies on microbial $\beta$-D-glucosidase immobilized in alginate gel beads," Process Biochemistry, vol. 30, no. 5, pp. 421-426, 1995.

[16] A. Martino, P. G. Pifferi, and G. Spagna, "Immobilization of $\beta$-glucosidase from a commercial preparation-part 2. Optimization of the immobilization process on chitosan," Process Biochemistry, vol. 31, no. 3, pp. 287-293, 1996.

[17] M. J. Somogyi, "Notes on sugar determination," The Journal of Biological Chemistry, vol. 195, no. 1, pp. 19-23, 1952.

[18] N. Ortega, M. D. Busto, and M. Perez-Mateos, "Optimisation of $\beta$-glucosidase entrapment in alginate and polyacrylamide gels," Bioresource Technology, vol. 64, no. 2, pp. 105-111, 1998.

[19] D. Jain and T. K. Ghose, "Cellobiose hydrolysis using Pichia etchellsii cells immobilized in calcium alginate," Biotechnology and Bioengineering, vol. 26, no. 4, pp. 340-346, 1984.

[20] R. C. Kamboj, N. Raghav, N. Nandal, and H. Singh, "Properties of cathepsin B immobilized in calcium alginate beads," Journal of Chemical Technology and Biotechnology, vol. 65, no. 2, pp. 149-155, 1996.

[21] E. Quiroga, C. O. Illanes, N. A. Ochoa, and S. Barberis, "Performance improvement of araujiain, a cystein phytoprotease, by immobilization within calcium alginate beads," Process Biochemistry, vol. 46, no. 4, pp. 1029-1034, 2011.

[22] F. Sahin, G. Demirel, and H. Tümtürk, "A novel matrix for the immobilization of acetylcholinesterase," International Journal of Biological Macromolecules, vol. 37, no. 2, pp. 148-153, 2005.

[23] N. Munjal and S. K. Sawhney, "Stability and properties of mushroom tyrosinase entrapped in alginate, polyacrylamide and gelatin gels," Enzyme and Microbial Technology, vol. 30, no. 5, pp. 613-619, 2002.

[24] E. Emregul, S. Sungur, and U. Akbulut, "Polyacrylamide-gelatine carrier system used for invertase immobilization," Food Chemistry, vol. 97, no. 4, pp. 591-597, 2006.

[25] M.-Y. Chang and R.-S. Juang, "Activities, stabilities, and reaction kinetics of three free and chitosan-clay composite immobilized enzymes," Enzyme and Microbial Technology, vol. 36, no. 1, pp. 75-82, 2005.

[26] M. A. P. Nunes, H. Vila-Real, P. C. B. Fernandes, and M. H. L. Ribeiro, "Immobilization of naringinase in PVA-alginate matrix using an innovative technique," Applied Biochemistry and Biotechnology, vol. 160, no. 7, pp. 2129-2147, 2010.

[27] B. A. Caldwell, "Enzyme activities as a component of soil biodiversity: a review," Pedobiologia, vol. 49 , no. 6, pp. 637-644, 2005. 
[28] T. Sato, T. Mori, T. Tosa, and I. Chibata, "Studies on immobilized enzymes-IX. Preparation and properties of aminoacylase covalently attached to halogenoacetylcelluloses," Archives of Biochemistry and Biophysics, vol. 147, no. 2, pp. 788-796, 1971.

[29] J. Yan, G. Pan, C. Ding, and G. Quan, "Kinetic and thermodynamic parameters of $\beta$-glucosidase immobilized on various colloidal particles from a paddy soil," Colloids and Surfaces $B$, vol. 79, no. 1, pp. 298-303, 2010.

[30] E. Su, T. Xia, L. Gao, Q. Dai, and Z. Zhang, "Immobilization of $\beta$-glucosidase and its aroma-increasing effect on tea beverage," Food and Bioproducts Processing, vol. 88, no. 2-3, pp. 83-89, 2010.

[31] M. Y. Arica, N. G. Alaeddinoğlu, and V. Hasirci, "Immobilization of glucoamylase onto activated pHEMA/EGDMA microspheres: properties and application to a packed-bed reactor," Enzyme and Microbial Technology, vol. 22, no. 3, pp. 152-157, 1998.

[32] R. Erginer, L. Toppare, S. Alkan, and U. Bakir, "Immobilization of invertase in functionalized copolymer matrices," Reactive and Functional Polymers, vol. 45, no. 3, pp. 227-233, 2000.

[33] D.-S. Jiang, S.-Y. Long, J. Huang, H.-Y. Xiao, and J.-Y. Zhou, "Immobilization of Pycnoporus sanguineus laccase on magnetic chitosan microspheres," Biochemical Engineering Journal, vol. 25, no. 1, pp. 15-23, 2005.

[34] A. de Queiroz, E. Passes, S. Alves, G. Silva, O. Higa, and M. Vítolo, "Alginate-poly(vinyl alcohol) core-shell microspheres for lipase immobilization," Journal of Applied Polymer Science, vol. 102, no. 2, pp. 1553-1560, 2006.

[35] A. Yahşi, F. Şahin, G. Demirel, and H. Tümtürk, "Binary immobilization of tyrosinase by using alginate gel beads and poly(acrylamide-co-acrylic acid) hydrogels," International Journal of Biological Macromolecules, vol. 36, no. 4, pp. 253-258, 2005.

[36] P. Ye, Z.-K. Xu, J. Wu, C. Innocent, and P. Seta, "Nanofibrous poly(acrylonitrile-co-maleic acid) membranes functionalized with gelatin and chitosan for lipase immobilization," Biomaterials, vol. 27, no. 22, pp. 4169-4176, 2006.

[37] L. Bravo, "Polyphenols: chemistry, dietary sources, metabolism, and nutritional significance," Nutrition Reviews, vol. 56, no. 11, pp. 317-333, 1998.

[38] C. Alasalvar, J. M. Grigor, D. Zhang, P. C. Quantick, and F. Shahidi, "Comparison of volatiles, phenolics, sugars, antioxidant vitamins, and sensory quality of different colored carrot varieties," Journal of Agricultural and Food Chemistry, vol. 49, no. 3, pp. 1410-1416, 2001. 

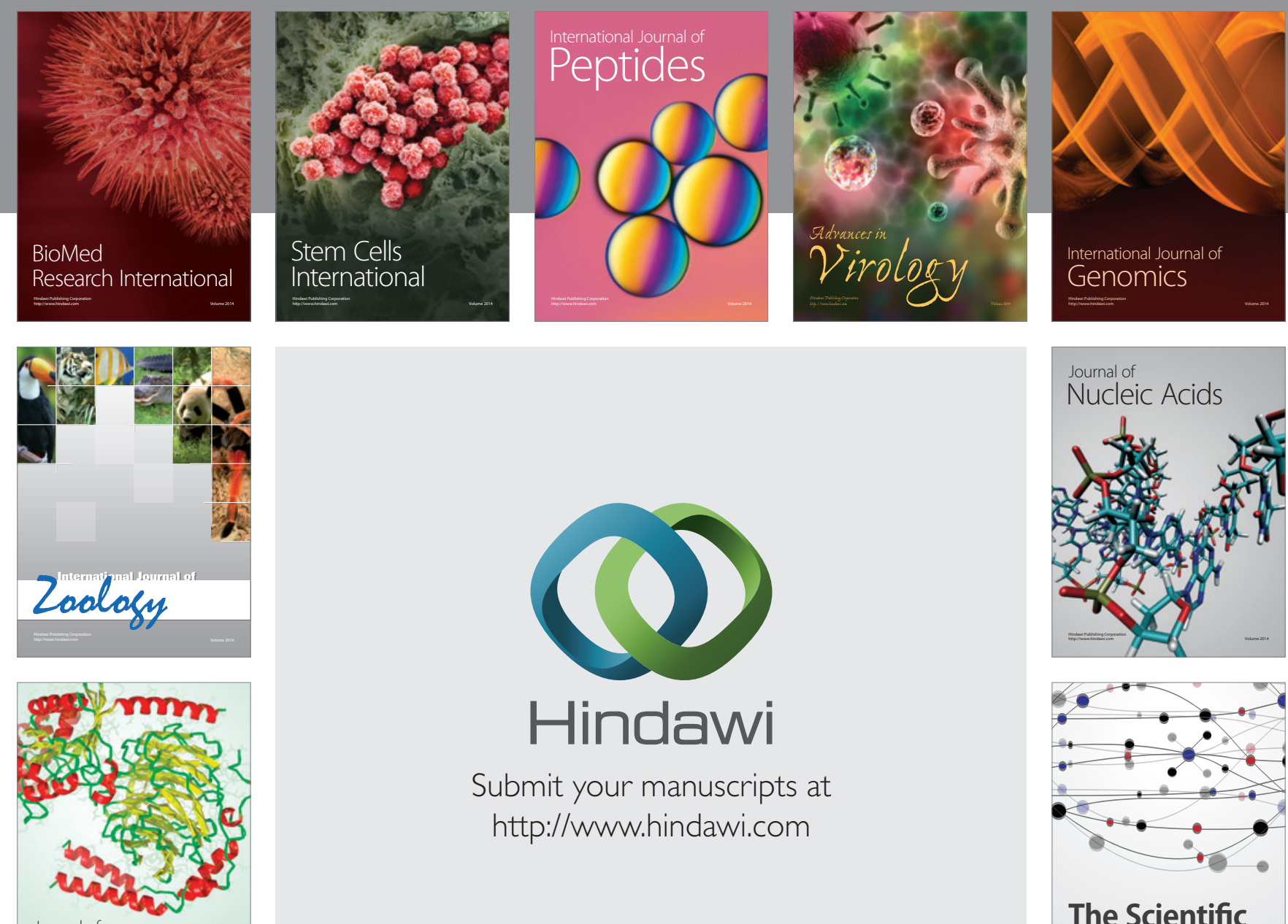

Submit your manuscripts at

http://www.hindawi.com

Journal of
Signal Transduction
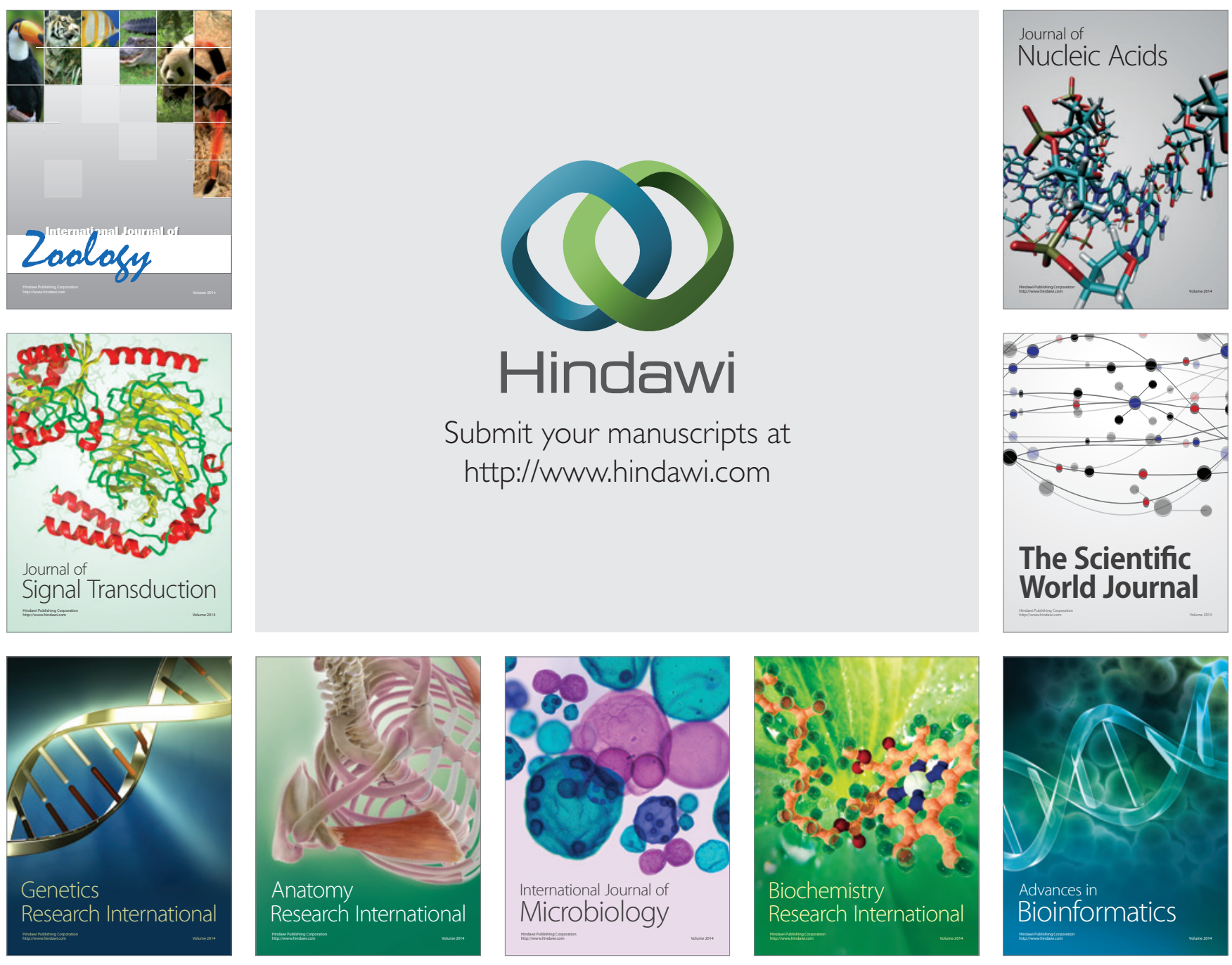

The Scientific World Journal
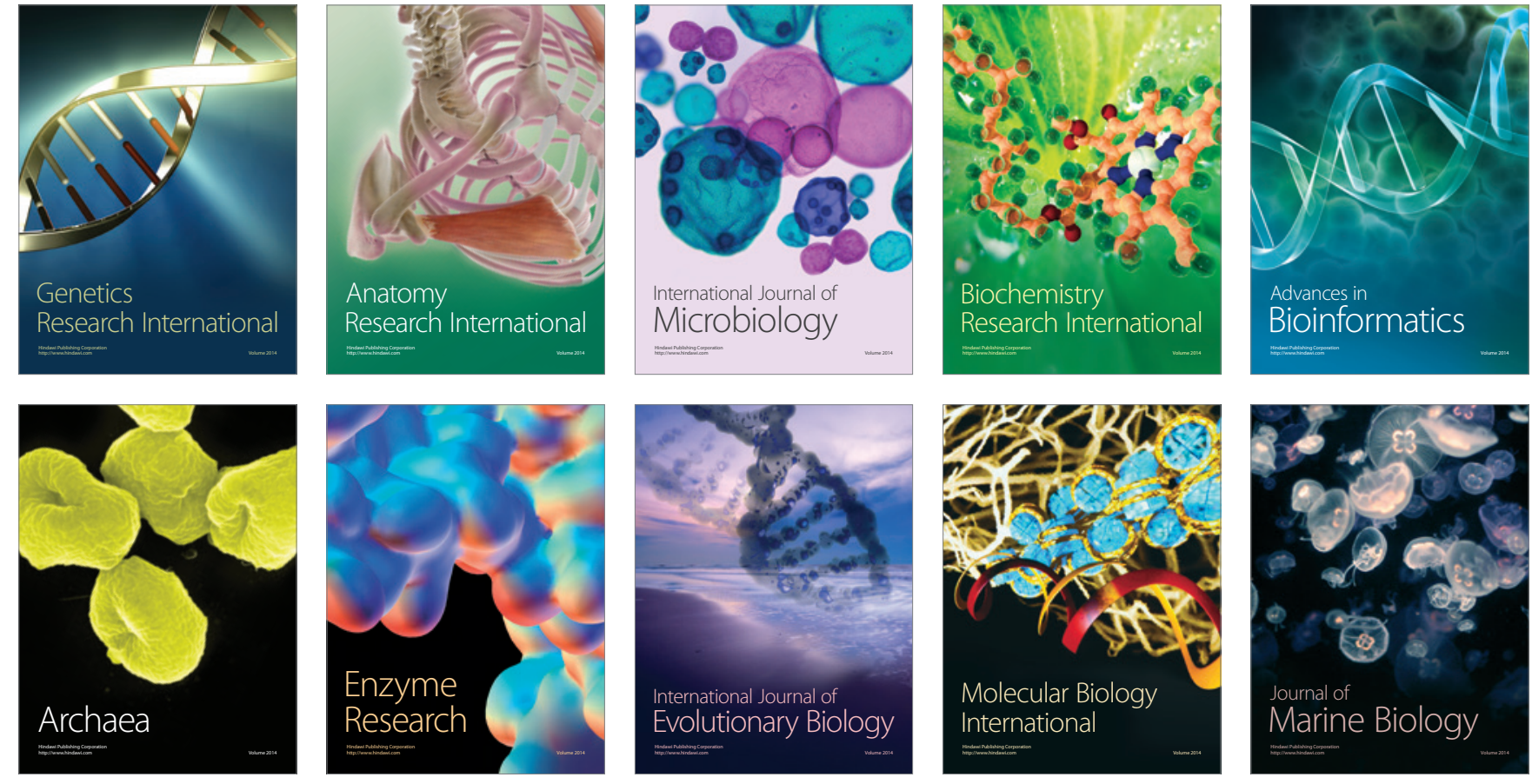